\title{
Teacher's Role in the Implementation of Character Education on Students
}

\author{
Zulkifli \\ Indonesian Language Education \\ Faculty of Teacher Training and Education \\ Universitas Lambung Mangkurat \\ Banjarmasin, Indonesia
}

\begin{abstract}
Teachers' duty is not only teaching, but also educating. Teachers are also known as a mentor, facilitator, learning resource, and learning manager. This article uses the literature to understand the teacher role in the implementation of character education on students. The teacher is one of the determining factors in achieving the success of the educational process. On the other hand, teachers must play a direct role in character education for their students In relation to character education, the teacher can carry out several activities, for example by involving students in the daily observations of people working in the community, activities in maintaining the environment, social activities, activities to improve mastery of science through reading, involving students in a meeting for then receive well the decision of the meeting, activities that instill the independence of students through the completion of tasks, and other activities that become parts of character education. In relation to the implementation of character education, teachers must set themselves as an example. The teachers should also be involved in various activities in which there are positive values, which then becomes a reference for their students.
\end{abstract}

Keywords-teacher's role; character education

\section{INTRODUCTION}

Education is regarded as a real effort to improve human quality. In a more specific term, it refers to an activity that is aimed to make students able to achieve success in their lives, become knowledgeable and skilled people, and have good attitudes based on which they can face the surrounding environment. Through education, students are expected to be human beings who behave commendably. Education is a conscious effort of adult humans to make their students able to acquire knowledge, skills, and embedded good attitudes in facing their future. Education in a broad sense is a human effort to improve the welfare of his life, which lasts for life, then in a special sense education is limited as an adult effort in guiding children who are immature to reach maturity [1].

One of the important things that need to be considered in the education process is about character education aimed at students. Indeed, over the past few years, character education has become one of the topics of study for many parties, especially for those involved in the education process. Then, practically it can be stated that the teacher is a central figure in character education aimed at students. Therefore, how do teachers portray themselves as central figures in this character education process, then it needs to be studied so that the existence of teachers is increasingly visible in the character education process itself.
The main resource in achieving quality education outcomes is the teacher. Indeed, many components determine the success of the education process. However, the position of the teacher is very important and basically, in the education process, the existence of the teacher is irreplaceable. Therefore, to improve the quality of education without prioritizing teacher quality improvement, it is not only contrary to common sense, but also an impossibility [2]. Therefore, the existence of teachers in the teaching and learning process in educational institutions (at all levels) is always a concern, as well as being considered as a determinant in achieving educational goals.

The success achieved in an educational process is usually associated with how high the quality of the teacher is. Conversely, if an educational process is considered to be less successful, it is usually the teacher who is considered the cause. Regardless of the person's assessment of the teacher, it should be a motivator for the teacher himself to improve himself. The teacher must be aware that he is the center of attention in achieving educational success. The teacher is one of the dominant factors that determine the success of students in transforming science and technology and internalizing ethics and morals [3].

The teacher is a professional worker, which among other things means that the teacher is working or carrying out his duties based on expertise, motivated by the provision of knowledge (which will be taught), provision of skills in interacting with students (relating to the management of students), provision in run the teaching and learning process, including attitudes and personalities as instructors and educators. A professional teacher is required with minimum requirements, among others, having adequate educational qualifications, having scientific competence, having good communication skills with their students, having a creative spirit, having a work ethic and a high commitment to the profession, and always developing themselves [2]. In this context, reference [4] put forward the term effective teacher. Then they stated that to be a professional teacher must have: good intellectual ability, able to understand the vision and mission of national education, have the ability to transfer knowledge to students, understand children's psychology development, understand how to organize the learning process, and have creativity and the art of educating.

\section{METHOD}

This research is a literature review. The reference is about the character education. Based on the reference, the character education, we will understand the role of the teacher in 
implementation the character education on the student, and the character value.

\section{RESULT AND DISCUSSION}

With the presence of teachers as a determinant of the success of the entire education process, the teacher can be called a central figure, including in the context of character education for students. The teacher is not just a teacher but as an educator. In fact, the teacher, by reference [5] is referred to as a learning resource (related to mastering the material), facilitator (providing services to students related to learning), learning manager, demonstrator (doing something so students understand what the teacher is saying), mentors, motivator, and evaluator.

As stated above that the teacher is one of the determining factors in achieving the success of the educational process, many of the designations attached to the teacher. Therefore, it is appropriate that the teacher is a central figure in the implementation of character education for students. In recent years, education experts, lecturers, and teachers in Indonesia have discussed or paid attention to character education. Basically, character education has existed for a long time, but it is less of a particular concern for those who are involved in education.

It's a good idea, in this section, about education to facilitate discussion of character education. Education is a real effort to deliver students to be mentally independent, towards maturity [6]. Character education is value education [2]. Furthermore, Wahyu explained that the study of values includes two main things, namely aesthetics and ethics or character, morals, and character. Character education is one of the main elements in the education process. That is, the education process is not only concerned with certain elements of knowledge and skills, but the affective element is also something very important, which specifically as well as separately is character education also needs the attention of schools or educational institutions in order to foster and develop students. Because character education is also intended as an education of values, the values which are the points of character education can be referred to as stated in the Ministry of National Education [2] namely: religious, honest, tolerant, disciplined, hard work, creative, independent, democratic, curiosity, national spirit, love of the homeland, respect for achievement, friendship/communication, love of peace, love of reading, caring for the environment, social care, and responsibility.

In relation to the existence of the teacher as a central figure in the implementation of character education, it is appropriate that the teacher himself has applied the values mentioned above so that he becomes the right person to be followed by his students. Therefore, before someone becomes a teacher, they must understand the values that are an important part of character education. Teachers must be able to be good examples for their students. On the other hand, the teaching profession is identical with the role of educating, such as guiding, fostering, caring for, or teaching [4]. Thus, teachers have diverse duties and roles in delivering their students to become human beings who are aware of themselves, ready to face their future, towards life that is able to adapt to their society and is expected to contribute to the progress of society. Therefore, the teacher must also be able to bring students closer to the community so that little by little the students understand their environment. This can be attributed to contextual learning [7].

Every teacher should have to equip themselves more. This is done because of the wide scope of the roles and duties of teachers in the process of education in schools, especially in the context of implementing character education. Teachers must explore certain values that will be instilled in their students [8]. The teacher is a central figure in the implementation of character education for students. The teacher also supports and fosters anything that is good from his students, on the contrary, the teacher suppresses anything that is not good for students [9]. The teacher is responsible for leaving the values and norms to the younger generation so that they occur value conservation, even though the process of education, the creation of new values [10], so that it appears that teachers not only teach or provide knowledge and skills, but also educate, including instilling values, specifically again is to play a direct role in character education, then the teacher in carrying out character education in the form of teaching knowledge about character, but doing the character building of the students themselves. In fact, in practice, students must be introduced to the values of character education itself, for example about discipline, honest, tolerance, hard work, creative, etc. In the next stage yes of course what is emphasized is how to apply these values, both in the lives of students in school and in the family and community environment.

Teachers are expected to be able to manage the teachinglearning process well, especially in the implementation of character education for their students. Therefore, there are several things that can be applied when the teacher focuses his learning in school (at the secondary school level), as stated below:

\section{A. Observation When People Work}

The teacher can bring students to the location, where farmers work in the fields. Students are given the opportunity to see firsthand how farmers work in their fields. Children are given direct lessons on how farmers are diligently doing their work. Students can be given the opportunity to interview farmers about agriculture. With this activity, students are expected to understand hard work and responsibility as part of the values in character education.

\section{B. Introductions between Communities}

Teachers hold discussions or meetings between communities that are of different ethnic or religious backgrounds. Students directly feel the existence of a multicultural situation, so that they will increase their awareness that in society there is a lot of diversity, so they feel the need for tolerance.

\section{Attending and Doing Activities on Time}

The teacher holds certain activities, outside of class hours with a detailed schedule. Students are involved in every activity by doing tasks. The teacher follows how students 
complete their tasks or in groups for later, the results are reported to the teacher. This activity is part of character education for the values of discipline that need to be applied to students.

\section{Caring for the Environment}

The teacher gives an explanation of the importance of a clean environment, an environment free from the spread of germs. The teacher must give an example of how to create cleanliness around the school, for example by throwing trash in its place, inviting students to sweep the schoolyard, and the teacher can also invite students to travel to enjoy the beauty of nature. If at all possible, the teacher does the planting movement. This is part of the application of environmental care values. In other words, the teacher must do real in terms of caring for the environment.

\section{E. Love Reading}

Students must be encouraged to read diligently. They are given the understanding that reading is part of the way to gain knowledge. The teacher directs his students to read diligently. On certain occasions, teachers need to choose reading material for their students. Of course, the teacher himself must read diligently.

\section{F. Respecting Joint Decisions}

Children are accustomed to respecting joint decisions. Teachers can hold meetings, for example in the form of meetings when going to carry out tourism activities. Meetings that resulted in these decisions must be adhered to by all meeting participants, even though previously there were differences of opinion. This is the application of democratic values. These democratic values will be able to shape the students' souls that everyone must respect what has been shared and unselfish.

\section{G. Social Care}

The teacher strives to give awareness to their students about the importance of caring for community members. Therefore, in the event of a natural disaster or fire, the teacher invites his students to help the victim, in the form of goods, money or energy in accordance with their abilities and circumstances. Things that need to be considered include students not being burdened with something excessive.

\section{H. Practicing Independence}

The teacher trains students' independence by giving assignments that are solving a problem, in accordance with the ability of students. The teacher only provides guidance, then his students try to solve it without the help of the teacher. The teacher keeps abreast of the development of his students in carrying out assignments.

What the teacher does in implementing character education is varied. Teachers always focus their attention on values education so that their students understand and absorb the importance of the values that must be applied in their relationships at school and as a provision for their relationships in the family and in society.

\section{CONCLUSION}

The role of the teacher in achieving the education process is very large. Therefore, every teacher must understand that he is not only teaching, but also educating in the broadest sense. The teacher is also a determinant in the implementation of character education for students. Teachers must be able to provide good examples, especially related to the implementation of character education. Students must be given real experience in applying values as part of character education. Thus, students directly feel the benefits of the applied values that they should have. Therefore, teachers need to equip themselves with various abilities, especially in managing students, especially to achieve the success of character education.

\section{REFERENCES}

[1] U. Sadulloh, Pengantar Filsafat Pendidikan. Bandung: Alfabeta, 2014.

[2] Wahyu, Membangun Pendidikan. Banjarmasin: FKIP Universitas Lambung Mangkurat, 2017.

[3] I. D. Sidi, Menuju Masyarakat Belajar. Jakarta: Paramadina. 2001.

[4] Suyanto and J. Asep, Menjadi Guru Profesional-Strategi Meningkatkan Kualifikasi dan Kualitas Guru di Era Global. Jakarta: Erlangga, 2013.

[5] W. Sanjaya, Strategi Pembelajaran Berorientasi Standar Proses Pendidikan. Jakarta: Kencana Prenada Media Group, 2012.

[6] R. Hadi, Pembelajaran Nilai Kejujuran dalam Berbisnis. Yogyakarta: Aswaja Pressendo, 2015.

[7] Hamdayama, Jumanta, Model dan Metode Pembelajaran Kreatif dan Berkarakter. Bogor: Ghalia Indoneisa, 2014.

[8] Wahyu, Pendidikan Karakter. Banjarmasin: FKIP Unlam Press, 2014.

[9] Crijns and Reksosiswono, Pengantar di dalam Praktik Penajaran dan Pendidikan. Jakarta: PN Pradnyataparamita, 1964.

[10] O. Hamalik, Pendidikan Guru Berdassarkan Pendekatan Kompetensi. Jakarta: PT Bumi Aksara, 2004. 